\title{
Rich and cold: diversity, distribution and drivers of fungal communities in patterned-ground ecosystems of the North American Arctic
}

\author{
I. TIMLING,${ }^{*}$ D. A. WALKER, ${ }^{*}$ C. NUSBAUM, $\dagger$ N. J. LENNON $\uparrow$ and D. L. TAYLOR* \\ *Department of Biology and Wildlife, University of Alaska Fairbanks, 101 Margaret Murie Building, 982N Koyukuk Dr., \\ Fairbanks, AK 99775, USA, †Broad Institute of MIT \& Harvard, 320 Charles Street, Cambridge, MA 02141, USA, \\ $\$$ Department of Biology, MSC03 2020, 1 University of New Mexico, Albuquerque, NM 87131, USA
}

\begin{abstract}
Fungi are abundant and functionally important in the Arctic, yet comprehensive studies of their diversity in relation to geography and environment are not available. We sampled soils in paired plots along the North American Arctic Transect (NAAT), which spans all five bioclimatic subzones of the Arctic. Each pair of plots contrasted relatively bare, cryoturbated patterned-ground features (PGFs) and adjacent vegetated between patterned-ground features (bPGFs). Fungal communities were analysed via sequencing of 7834 ITS-LSU clones. We recorded 1834 OTUs - nearly half the fungal richness previously reported for the entire Arctic. These OTUs spanned eight phyla, 24 classes, 75 orders and 120 families, but were dominated by Ascomycota, with one-fifth belonging to lichens. Species richness did not decline with increasing latitude, although there was a decline in mycorrhizal taxa that was offset by an increase in lichen taxa. The dominant OTUs were widespread even beyond the Arctic, demonstrating no dispersal limitation. Yet fungal communities were distinct in each subzone and were correlated with soil $\mathrm{pH}$, climate and vegetation. Communities in subzone $\mathrm{E}$ were distinct from the other subzones, but similar to those of the boreal forest. Fungal communities on disturbed PGFs differed significantly from those of paired stable areas in bPGFs. Indicator species for PGFs included lichens and saprotrophic fungi, while bPGFs were characterized by ectomycorrhizal and pathogenic fungi. Our results suggest that the Arctic does not host a unique mycoflora, while Arctic fungi are highly sensitive to climate and vegetation, with potential to migrate rapidly as global change unfolds.
\end{abstract}

Keywords: Arctic, bioclimatic gradient, community structure, diversity, fungi, patterned-ground ecosystems

Received 12 December 2013; revision received 5 March 2014; accepted 25 March 2014

\section{Introduction}

Fungi are ubiquitous components of soils, including Arctic soils, where they drive mineral and energy cycles, and influence the occurrence of other organisms as mutualists, decomposers and pathogens. Despite their ubiquity and importance for ecosystem function, we have just begun to uncover fungal biodiversity and distribution patterns in the Arctic (reviewed in Timling \& Taylor 2012). Ongoing climate change has been espe-

Correspondence: I. Timling, Fax: 907-474-6717;

E-mail: itimling@alaska.edu cially rapid in the Arctic, and long-term warming experiments demonstrate effects on plant and fungal communities (Walker et al. 2006; Clemmensen \& Michelsen 2006; Rinnan et al. 2007; Deslippe et al. 2011). After nearly two decades of warming, EMF communities associated with Betula nana, which is one of the most responsive shrubs to climate change in the Low Arctic, showed significant changes in community composition and structure with a 15 -fold increase in representation of the Cortinariaceae (Deslippe et al. 2011).

Although cold, the Arctic encompasses great variation in climate and vegetation, which has led to the 
designation of five bioclimatic subzones (A-E). The subzones are defined by summer warmth index (SWI) and plant growth forms. Subzone $\mathrm{A}$ is the coldest and is dominated by cushion forbs, mosses and lichens, while subzone $\mathrm{E}$ is the warmest and is characterized by low shrubs, tussock sedges and mosses. Total vascular plant species richness and cover increase from subzones A to E (Walker et al. 2005) (Table 1). Across the Arctic, patterned-ground features (PGFs), which in this study include nonsorted circles and small nonsorted polygons, are abundant (Washburn 1980; Walker et al. 2008). They are formed by permafrost processes and result in spatial heterogeneity of plant communities and soils at the submetre scale. The PGFs generally are composed of a central area that is highly disturbed by frost heave and covered variously with bare ground, biological soil crusts and plants adapted to the disturbance (Walker et al. 2008). Areas between the patterned-ground features (bPGFs) are more continuously vegetated and experience much less frost heave (Walker et al. 2008). The diameter of the PGFs typically ranges from 10 $30 \mathrm{~cm}$ in subzone A to $3 \mathrm{~m}$ in subzone C (Fig. 1b); they are nearly bare, with interspersed soil crusts, in subzones A-C, but are nearly entirely vegetated in subzone E (Raynolds et al. 2008; Walker et al. 2011). Environmental conditions within these features differ not only across the bioclimatic subzones, but also on a local scale, including variation in thermal regimes, thaw depth, nutrient content, soil moisture and carbon storage (Michaelson et al. 2008), which is reflected in differences in the associated plant communities (Kade et al. 2005; Vonlanthen et al. 2008; Walker et al. 2011).

Table 1 Locations and characteristics of the zonal mesic sampling sites along the North American Arctic Transect (NAAT)

\begin{tabular}{|c|c|c|c|c|c|c|c|c|}
\hline Location & Site & $\begin{array}{l}\text { Latitude/ } \\
\text { longitude }\end{array}$ & $\begin{array}{l}\text { Bioclimatic } \\
\text { subzone }\end{array}$ & $\begin{array}{l}\mathrm{SWI}^{*} \\
\left({ }^{\circ} \mathrm{C}\right)^{\dagger}\end{array}$ & $\begin{array}{l}\text { Soil } \\
\mathrm{pH}^{\dagger}\end{array}$ & $\begin{array}{l}\text { Soil } \\
\mathrm{C}: \mathrm{N}^{\dagger}\end{array}$ & Physiognomic unit ${ }^{+}$ & Plant community ${ }^{*}$ \\
\hline \multirow[t]{2}{*}{$\begin{array}{l}\text { Isachsen, Ellef } \\
\text { Ringnes } \\
\text { Island (ER) }\end{array}$} & $\mathrm{PGF}^{\S}$ & $\begin{array}{l}78^{\circ} 47.106^{\prime} \mathrm{N} \\
103^{\circ} 33.09^{\prime} \mathrm{W}\end{array}$ & A & 3.6 & 6.5 & 13.60 & Lichen, forb barren (B1b) & $\begin{array}{l}\text { Puccinellia } \\
\text { angustata-Papaper } \\
\text { radicatum }\end{array}$ \\
\hline & bPGF" & & & & 6.4 & 13.45 & $\begin{array}{l}\text { Rush/grass, forb, } \\
\text { moss tundra (G1) }\end{array}$ & $\begin{array}{l}\text { Saxifrago-Parmelia } \\
\text { omphalodes spp. } \\
\text { glacialis }\end{array}$ \\
\hline \multirow{2}{*}{$\begin{array}{l}\text { Mould Bay } \\
\text { Prince Patrick } \\
\text { Island (PP) }\end{array}$} & PGF & $\begin{array}{l}76^{\circ} 13^{\prime} 42.8^{\prime \prime} \mathrm{N} \\
119^{\circ} 17^{\prime} 57.9^{\prime \prime} \mathrm{W}\end{array}$ & B & 6.2 & 7.4 & 14.74 & Lichen, forb barren (B1b) & $\begin{array}{l}\text { Hypogymnia } \\
\text { subobscura-Leproloma }\end{array}$ \\
\hline & $\mathrm{bPGF}$ & & & & 7.1 & 15.23 & $\begin{array}{l}\text { Graminoid, prostrate } \\
\text { dwarf shrubs forb } \\
\text { tundra (G2) }\end{array}$ & $\begin{array}{l}\text { Orthotrichum } \\
\text { speciosum-Salix arctica }\end{array}$ \\
\hline \multirow[t]{2}{*}{$\begin{array}{l}\text { Green Cabin, } \\
\text { Banks Island } \\
\text { (BI) }\end{array}$} & PGF & $\begin{array}{l}73^{\circ} 13^{\prime} 10^{\prime \prime} \mathrm{N} \\
119^{\circ} 33^{\prime} 33^{\prime \prime} \mathrm{W}\end{array}$ & $\mathrm{C}$ & 14.7 & 8.4 & 46.12 & Bare ground (B1a) & $\begin{array}{l}\text { Puccinellia } \\
\text { angustata-Potentilla } \\
\text { vahliana }\end{array}$ \\
\hline & bPGF & & & & 7.9 & 25.14 & $\begin{array}{l}\text { Prostrate dwarf shrub, } \\
\text { herb tundra (P1a) }\end{array}$ & $\begin{array}{l}\text { Dryas integrifolia-Carex } \\
\text { rupestris }\end{array}$ \\
\hline \multirow[t]{2}{*}{$\begin{array}{l}\text { Howe Island } \\
(\mathrm{HI})\end{array}$} & PGF & $\begin{array}{l}70^{\circ} 18^{\prime} 54^{\prime \prime} \mathrm{N} \\
147^{\circ} 59^{\prime} 37^{\prime \prime} \mathrm{W}\end{array}$ & $\mathrm{C}$ & 14.7 & 8.6 & 49.99 & Lichen, forb barren (B1b) & $\begin{array}{l}\text { Braya purpurascens- } \\
\text { Puccinellia angustata }\end{array}$ \\
\hline & bPGF & & & & 7.8 & 39.28 & $\begin{array}{l}\text { Prostrate dwarf shrub, } \\
\text { herb tundra (P1a) }\end{array}$ & $\begin{array}{l}\text { D. integrifolia-Salix } \\
\text { arctica }\end{array}$ \\
\hline \multirow[t]{2}{*}{$\begin{array}{l}\text { Franklin } \\
\text { Bluffs } \\
(\mathrm{FB})\end{array}$} & PGF & $\begin{array}{l}69^{\circ} 40^{\prime} 28^{\prime \prime} \mathrm{N} \\
148^{\circ} 43^{\prime} 16^{\prime \prime} \mathrm{W}\end{array}$ & $\mathrm{D}$ & 27.0 & 8.0 & 21.99 & $\begin{array}{l}\text { Lichen, forb barren; } \\
\text { Prostrate dwarf } \\
\text { shrub tundra } \\
\text { (B1b, P1a) }\end{array}$ & $\begin{array}{l}\text { Junco biglumis- } \\
\text { Dryadetum integrifoliae } \\
\text { typicum/pedicularetosum }\end{array}$ \\
\hline & $\mathrm{bPGF}$ & & & & 8.2 & 38.39 & $\begin{array}{l}\text { Nontussock sedge, dwarf } \\
\text { shrub, moss tundra (G3) }\end{array}$ & $\begin{array}{l}\text { Dryado-integrifoliae- } \\
\text { Caricetum bigelowii }\end{array}$ \\
\hline \multirow[t]{2}{*}{$\begin{array}{l}\text { Happy } \\
\text { Valley } \\
\text { (HV) }\end{array}$} & PGF & $\begin{array}{l}69^{\circ} 08^{\prime} 50^{\prime \prime} \mathrm{N} \\
148^{\circ} 50^{\prime} 49^{\prime \prime} \mathrm{W}\end{array}$ & $\mathrm{E}$ & 30.2 & 5.2 & 16.71 & $\begin{array}{l}\text { Liverwort, moss barren; } \\
\text { Prostrate dwarf shrub, } \\
\text { herb moss tundra (B1c) }\end{array}$ & $\begin{array}{l}\text { Anthelia juratzkana- } \\
\text { Juncus biglumis }\end{array}$ \\
\hline & $\mathrm{bPGF}$ & & & & 5.0 & 19.43 & $\begin{array}{l}\text { Tussock sedge, dwarf } \\
\text { shrub, moss tundra (G4) }\end{array}$ & $\begin{array}{l}\text { Sphagno-Eriophoretum } \\
\text { vaginati }\end{array}$ \\
\hline
\end{tabular}

*Summer warmth index (SWI) is the sum of the monthly means above $0{ }^{\circ} \mathrm{C}$.

†Data are from Walker et al. (2011).

\$Physiognomic units of the Circumpolar Arctic Vegetation Map (CAVM). Data are from Raynolds et al. (2008).

${ }^{\S}$ Patterned-ground feature (PGF).

${ }^{\Phi}$ between patterned-ground feature (bPGF). 

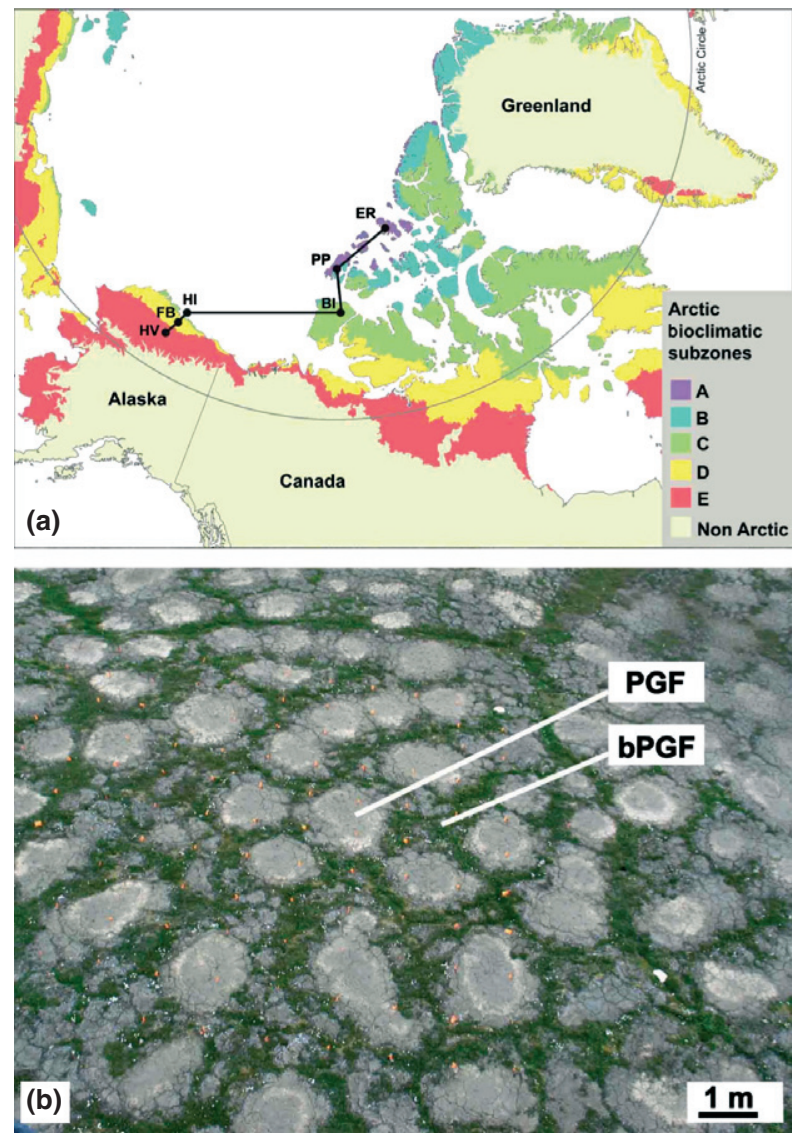

Fig. 1 Map of (a) sampling sites along the North American Arctic Transect (NAAT), (b) patterned-ground features (PGF) and areas between patterned-ground features (bPGF) at Howe Island (subzone C).

Through the process of cryoturbation, which moves soil organic carbon deeper into the soil towards the permafrost table, small patterned-ground features are considered major contributors to carbon storage in the Arctic (Ping et al. 2008).

While all major fungal phyla are present in arctic soils (Wallenstein et al. 2007), most molecular studies have focused on ectomycorrhizal fungi (EMF) (Bjorbaekmo et al. 2010; Fujiyoshi et al. 2011; Blaalid et al. 2012; Fujimura \& Egger 2012; Geml et al. 2012b; Timling et al. 2012). Patterns that emerge from studies of EMF associated with abundant dwarf shrubs include speciesrich fungal communities that are dominated by several fungal families such as Thelephoraceae, Inocybaceae, Sebacinaceae, Cortinariaceae and Pyronemataceae. Several studies have reported no decline in EMF species richness with latitude (Bjorbaekmo et al. 2010; Timling et al. 2012). Furthermore, it appears that some arctic fungal species, including certain EMF (Geml et al. 2012b; Timling et al. 2012), lichens (Geml et al. 2012a) and saprotrophic fungi (Jurgens et al. 2009), have wide distributions. Despite the wide distributions of dominant species, EMF community structure varied gradually with latitude, along the North American Arctic Transect (NAAT) (Timling et al. 2012). Other than mycorrhizal taxa, no information exists on the diversity and distribution patterns of total fungal communities in soil across all five bioclimatic subzones of the Arctic.

Early work in the Alaskan tundra included sporocarp surveys of patterned-ground features such as high- and low-centred ice wedge polygon tops, rims and troughs (Laursen 1975). EMF species were most abundant on polygons tops and rims, while more decomposers occurred in the low-centre basins and troughs (Laursen 1975). Prior molecular studies of individual sites in cold-dominated biomes have shown that fungal communities are correlated with regional climate, soil chemistry and plant communities, which are in turn associated with various landscape features (Wallenstein et al. 2007; Yergeau et al. 2007; Fujimura \& Egger 2012). Similarly, EMF communities associated with Dryas integrifolia and Salix arctica along the NAAT were strongly correlated with regional environmental factors corresponding to geology and soil properties, glaciation history, climate and plant productivity, while host plant identity did not have a significant effect (Timling et al. 2012). Still, key drivers for total fungal communities in patterned-ground ecosystems across the full bioclimatic gradient are unknown.

In the present study, we use molecular methods to examine variation in soil fungi associated with zonal soils of small patterned-ground features along the NAAT (Walker et al. 2008). A comprehensive environmental data set for the NAAT was used to investigate correlations between fungal communities and environmental factors (Walker et al. 2011).

Specifically, we addressed the following questions:

1 What taxa of soil fungi occur within and adjacent to small patterned-ground features in the Arctic?

2 How do species richness and composition of soil fungal communities vary (i) between patterned-ground features and (ii) across the latitudinal and bioclimatic gradient in the Arctic?

3 What are the primary environmental drivers of fungal community composition in the Arctic?

\section{Material and methods}

\section{Study areas and patterned-ground features}

We sampled soils at zonal sites from six locations along the North American Arctic Transect (NAAT) (see Fig. 1 in Walker et al. 2008 for photographs of the sites), 
representing the five bioclimatic subzones (A through E) of the Arctic (CAVM-Team 2003) (Fig. 1a, Table 1). Zonal sites have mesic vegetation that developed under the existing climate on fine-grained soils with no extreme moisture, slope, soil chemistry or disturbance (Vysotsky 1909; Razzhivin 1999). The patterned-ground features varied from $20-30 \mathrm{~cm}$ small nonsorted circles, mostly between Eriophorum vaginatum tussocks, in subzone E to 2-3 $\mathrm{m}$ diameter, well-developed nonsorted circles in subzones C and D to small, 20-30 cm nonsorted polygons in subzones A and B. The cover of PGFs in zonal sites across the NAAT ranged from $14 \%$ in subzone $\mathrm{E}$ to $60 \%$ and $64 \%$ in subzones A and B (Raynolds et al. 2008). Nonsorted circles are mainly a consequence of differential frost heave (Peterson \& Krantz 2008), whereas nonsorted polygons are a result of fine-scale thermal contraction and desiccation cracking (Washburn 1980). Frost heave in bPGFs ranges from 1-9 cm and in PGFs from 4-20 cm (Walker et al. 2008).

To broaden the environmental context of our study, we also sampled dry sites in subzones A and B and one wet site in subzone B (Table S1, Supporting Information). All sites were extensively studied by members of the 'Biocomplexity Project' on the same or prior expeditions (Kade et al. 2005; Michaelson et al. 2008; Raynolds et al. 2008; Vonlanthen et al. 2008; Walker et al. 2008, 2011).

\section{Sampling and processing}

Soil samples were collected in July and August in 2005, 2006 and 2007. At each site, we collected 20 randomly chosen soil cores $(1.8 \mathrm{~cm}$ diameter) from each of the five selected PGFs and the five adjacent bPGFs. The sampling was $\leq 15 \mathrm{~m}$ from the $10 \times 10 \mathrm{~m}$ grids where the vegetation, active layer and snow depth were mapped in detail (Raynolds et al. 2008). Climate data were obtained from automated climate stations near the grids (http://permafrost.gi.alaska.edu), and soil data were provided by Michaelson et al. (2008).

Each soil core included organic and mineral horizons from the upper 5-10 cm. The 20 soil cores from each feature (PGF, bPGF) were immediately pooled for each feature and stored in 50-mL Falcon tubes in liquid nitrogen and later at $-80{ }^{\circ} \mathrm{C}$. A total of 100 pooled soil samples (2000 cores) were collected along the NAAT (60 mesic +30 dry +10 wet sites). Prior to DNA extraction, all soils were lyophilized and ground at $4{ }^{\circ} \mathrm{C}$ using $0.8-\mathrm{cm}$ steel beads on a Genie Vortex-2 (Scientific Industries). Visible roots were removed with forceps prior ball-milling of the soils.

\section{Molecular analysis}

We followed the approach described in Taylor et al. (2014). In brief, we extracted genomic DNA of soil from each pooled sample, quantified extracted DNA and normalized it to $4 \mathrm{ng} / \mu \mathrm{L}$. Then, we amplified the region of the complete internal transcribed spacer (ITS) and partial large subunit (LSU) using a tagging approach as described in Taylor et al. (2008). We used the fungalspecific primer ITS1F-L (Gardes and Bruns 1993), which is slightly elongated to increase specificity, and a tagged version of primer TW13 (White et al. 1990). For each soil DNA extract, six replicate PCRs were performed and pooled. We removed small fragments, concentrated DNA and normalized the purified PCR products to $25 \mathrm{ng} / \mu \mathrm{L}$. The pooled fragments were cloned, and ligation reactions were shipped frozen to the BROAD Institute of MIT and Harvard University, where automated transformation, plating, colony picking, Templiphi reactions and sequencing were performed. M13-F and M13$\mathrm{R}$ were used as external vector primers. Twelve clone libraries with at least 1536 clones per library were sequenced.

\section{Sequence clean-up}

In order to retain only high-quality fungal sequences, we followed the approach outlined in Taylor and Houston (2011; Taylor et al. 2014). In brief, low-quality bases at the ends of sequence reads were trimmed and vector sequences were removed.

The two sequences per clone were assembled and then assigned to a sample by their tag (Taylor et al. 2008) after which orientations were corrected, low-quality bases were changed to $\mathrm{Ns}$ and sequences with excess Ns removed using a set of Perl scripts. The sequences passing these quality control steps were submitted to OTUpipe (Edgar et al. 2011), which uses Uclust and Uchime (Edgar et al. 2011) to cluster sequences into operational taxonomic units (OTUs) and detect chimeric sequences. We clustered sequences at a sequence similarity of $97 \%$ across the ITS and partial LSU. Chimeric sequences with a score $>1.0$ were removed. To identify and eliminate nonfungal sequences, we used MEGABLAST (Altschul et al. 1997) to search for matches for each OTU in NCBI and assigned them to taxonomic groups at the kingdom level using MEGAN 4.62.7 (Huson et al. 2007). OTU sequences that were not assigned to fungi were aligned, followed by the extraction of the $5.8 S$ region and the LSU, which were then added to a master alignment of known organisms. A phylogenetic tree was then constructed, where sequences were scored by clade. All nonfungal and inconclusive sequences were eliminated from the data set.

We chose a representative sequence for each OTU by using a BLAST search with the OTU consensus sequence as query against the clone sequences contained within the OTU cluster, then chose a real sequence most 
similar (in most cases identical) to the consensus. In order to identify each OTU, we extracted the ITS1-5.8SITS2 region from the chosen representative sequence and submitted them again to BLAST search at NCBI, excluding environmental sequences. In cases where the ITS region was too short $(<200 \mathrm{bp})$, we used the partial LSU region for this step. We used $90 \%$ coverage and a range of similarity values as cut-offs for various taxonomic levels. In the ITS1-5.8S-ITS2 region, we used similarities of $\geq 97 \%$ for the species level, a range from $<97$ to $>93 \%$ for the genus and a range from $<93 \%$ to $>83 \%$ for family level. In the LSU region, we applied $\geq 99 \%$ for the species level, $\geq 97.5 \%$ for the genus level and $\geq 95.5 \%$ for the family level, based on comparisons of identity levels in linked ITS and LSU regions from an array of taxa (D. L. Taylor, unpublished data). A representative sequence from each OTU was deposited in GenBank under the Accession nos KC965108-KC966374 and KF296719-KF297285.

\section{Diversity analysis}

Fungal diversity was assessed across all sampled sites, including wet, mesic and dry sites. In contrast, analyses pertaining to the bioclimatic gradient were restricted to mesic sites, because we were not able to sample dry and wet sites at each location along the gradient. Fungal species richness (Mao Tau, Chao1) was calculated after rarefying clone numbers across the five PGF and bPGF communities of each location to the minimum number of clones (258 clones) in any sample using Estimate S 8.0 (Colwell 2006). Rarefaction curves for all fungi at each bioclimatic subzone and for mycorrhizal fungi were computed in Estimate $S 8.0$ by randomly subsampling the observed OTU abundance 50 times. To analyse how species richness of the various functional groups changed along the latitudinal gradient, we assigned the OTUs to the functional groups of lichen-forming fungi (referred to as lichens hereafter), mycorrhizal fungi (including ectomycorrhizal, ericoid, arbuscular and dark septate fungi), which were based on identification at the genus level, and a third group comprising saprotrophic, pathogenic and remaining fungi that were identified from family to phylum level (and therefore had undetermined ecologies). A parallel set of analyses compared yeast vs. nonyeast OTUs and pigmented vs. nonpigmented OTUs, again considering only OTUs identified at least to genus. Due to unequal sample numbers across the sites, we calculated the proportional OTU richness for each functional group at each site. To determine the relationship of observed and estimated species richness of the rarified OTUs and the relative OTU richness for each functional group with increasing latitude, we performed a linear regression in R (R-Development Team 2008).

\section{Ordination analysis}

We used the nonmetric multidimensional scaling (NMDS) ordination in PC-ORD5 to examine the relationship between fungal communities and environmental factors along the bioclimatic gradient (McCune \& Mefford 2006). The environmental matrix included two categorical variables (bioclimatic subzone and PGF vs. bPGF) and 64 quantitative variables related to geographical location, soil, climate and vegetation, which are listed in Table S2 (Supporting Information). Climate factors included $\mathrm{TDD}_{\text {soil }}$ and $\mathrm{TDD}_{\text {air }}$ (thawing degree days for soil and the air temperature, which is the sum of mean daily temperatures $>0{ }^{\circ} \mathrm{C}$ over a year), SWI (summer warmth index, which is the sum of mean monthly temperatures $>0{ }^{\circ} \mathrm{C}$ over a year in thawing degree months, ${ }^{\circ} \mathrm{C}$ mo), $\mathrm{FDD}_{\text {soil }}$ and $\mathrm{FDD}_{\text {air }}$ (freezing degree days for the soil and air, which is the yearly sum of mean daily temperatures $<0{ }^{\circ} \mathrm{C}$ ). Vegetation data included NDVI (normalized difference vegetation index), which is an index of vegetation greenness and is commonly used as indicator for biomass (Walker et al. 2011). Laboratory processes and the elimination of clone sequences during sequence clean-up resulted in different clone numbers per site. Therefore, we normalized the clone number by site totals and excluded OTUs that were found in fewer than two sites prior to analysis. We used the abundance-based Sorensen dissimilarity index (Bray-Curtis) as the distance measure. A three-dimensional solution with instabilities below 0.00001 best described the data. Significance of stress values was tested through 500 iterations of Monte Carlo randomization.

To investigate whether fungal communities varied statistically from random assembly among the bioclimatic subzones, and between PGF and bPGF, we applied multiple response permutation procedures (MRPP) in PC-ORD, using the Bray-Curtis index. In order to determine how environment is related to the abundance of the dominant fungal families along the bioclimatic gradient, we calculated Spearman rank correlations between the two strongest environmental factors identified by NMDS (thawing degree days of the air $\left(\mathrm{TDD}_{\mathrm{air}}\right), \mathrm{pH}$ ) and the most abundant families. To investigate the effects of plant communities and environment (Kade et al. 2005; Vonlanthen et al. 2008; Walker et al. 2011) on the fungal communities, we performed partial Mantel tests based on 999 permutations in $\mathrm{R}$.

\section{Distribution of OTUs}

To determine the minimum geographical distribution of the 50 most abundant OTUs, we recorded the location of the five top matches from GenBank. In addition, we 
conducted an indicator species analysis in PC-ORD to investigate whether there were individual OTUs that were specific to PGFs, bPGFs or particular bioclimatic subzones.

\section{Results}

\section{Fungal diversity in the Arctic}

A total of 7834 fungal clones were grouped into 1834 OTUs. Based on BLAST searches in GenBank, OTUs could be identified at varying levels of taxonomic precision. The most precise level at which OTUs could be assigned was species for $18.9 \%$, genus for $19.4 \%$, family for $23.3 \%$, order for $28.4 \%$ and phylum for $10 \%$ of all OTUs. The OTUs spanned eight phyla, 24 classes, 75 orders, 120 families and 214 genera (Table S3, Supporting Information). Ascomycota dominated communities with 4850 clones (1211 OTUs), followed by Basidiomycota with 2706 clones (486 OTUs). The Ascomycota comprised 75 families, with Verrucariaceae being the most abundant (803 clones) and the most diverse (97 OTUs), followed by Helotiaceae (241 clones, 67 OTUs) and Herpotrichiellaceae $(133,45)$. The Basidiomycota contained 36 families with Inocybaceae being the most abundant (817 clones) and most diverse (86 OTUs), followed by Thelephoraceae $(676,82)$ and Cortinariaceae $(349,17)$. The Chytridiomycota included 5 families. Zygomycota, Glomeromycota, Blastocladiomycota and Neocallimastigomycota were represented by one family each, while Cryptomycota were only identified at the phylum level (Table S4, Supporting Information). Approximately a fifth of the fungi were lichens ( $18 \%$ of all clones and
$22.5 \%$ of all OTUs). More than half of the OTUs (1003) were singletons (Table S3, Supporting Information). The rank abundance curve across all sites showed a few abundant and many rare OTUs (data not shown). The rarefaction curves from the mesic sites did not approach an asymptote (data not shown), indicating that we failed to saturate fungal diversity. The 50 most abundant species included fungi of various functional guilds, such as ectomycorrhizas, lichens, saprotrophs, pathogens and endophytes (Fig. 2). BLAST searches in GenBank for matching sequences at the species level showed that the 50 most abundant OTUs are widely distributed within and outside the Arctic, with matching sequences from both hemispheres (Table S5, Supporting Information). However, matches at the species level to OTU16 (Inocybe sp.) were restricted to the Arctic.

\section{Species richness along the latitudinal gradient}

Linear regression analysis showed no relationship of observed (Mao Tau) and estimated (Chao1) fungal species (OTU) richness with latitude (Fig. 3a). Observed mean species richness along the gradient was $109 \pm 18$ OTUs (mean \pm SD) in the PGFs and $112 \pm 12$ OTUs in bPGF, which was not significantly different $(P=0.8477)$. At the site level, we found an average of $245 \pm 30$ OTUs (Mao Tau). Estimated species richness (Chao1) was higher than the Mao Tau for the PFG (291 \pm 43 OTUs), bPGFs (298 \pm 76 OTUs) and for the sites (561 \pm 94 OTUs). Rare species, including singletons and doubletons, accounted for $75.4 \pm 3.4 \%$ (mean $\pm \mathrm{SD}$ ) of the species richness at each site. When

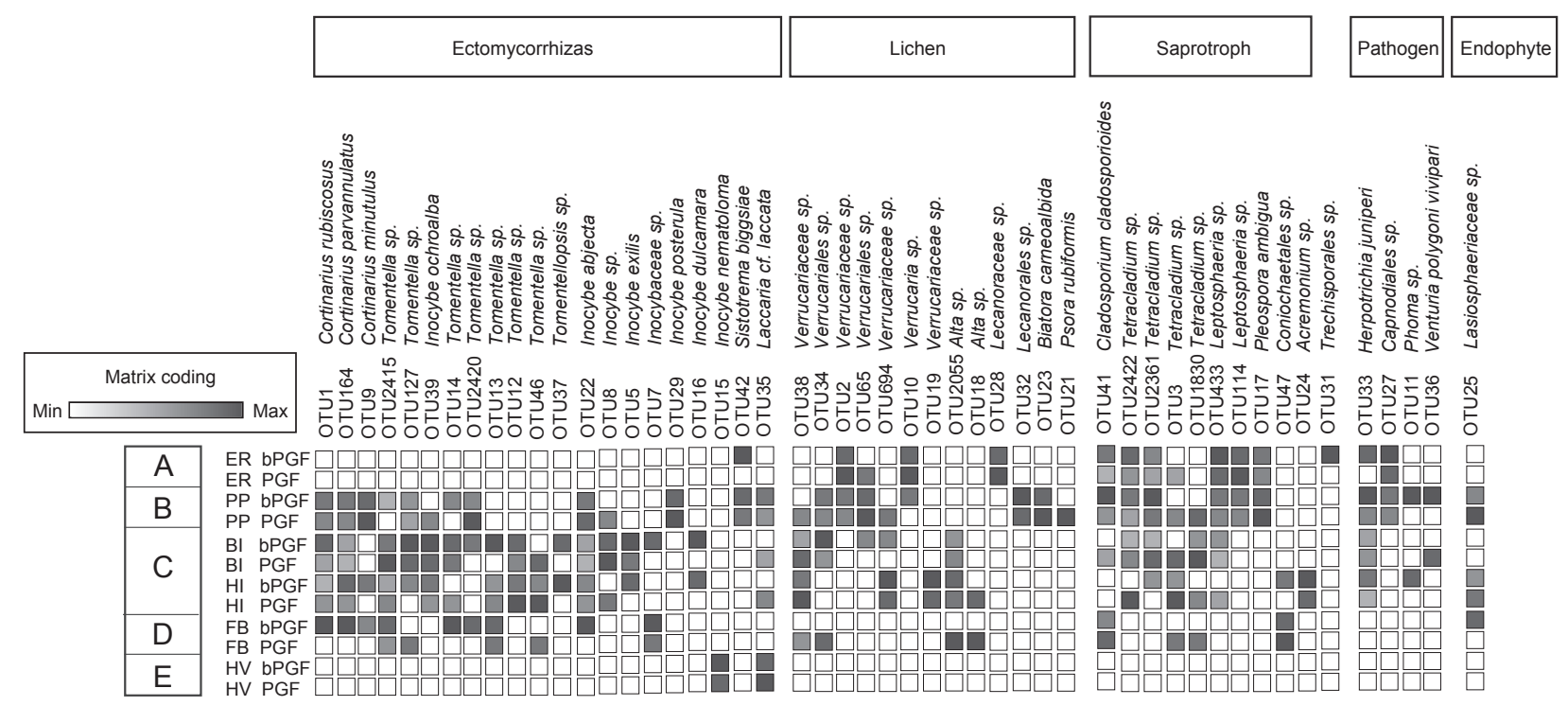

Fig. 2 Distribution of the 50 most abundant operational taxonomic units (OTUs) along the NAAT. 

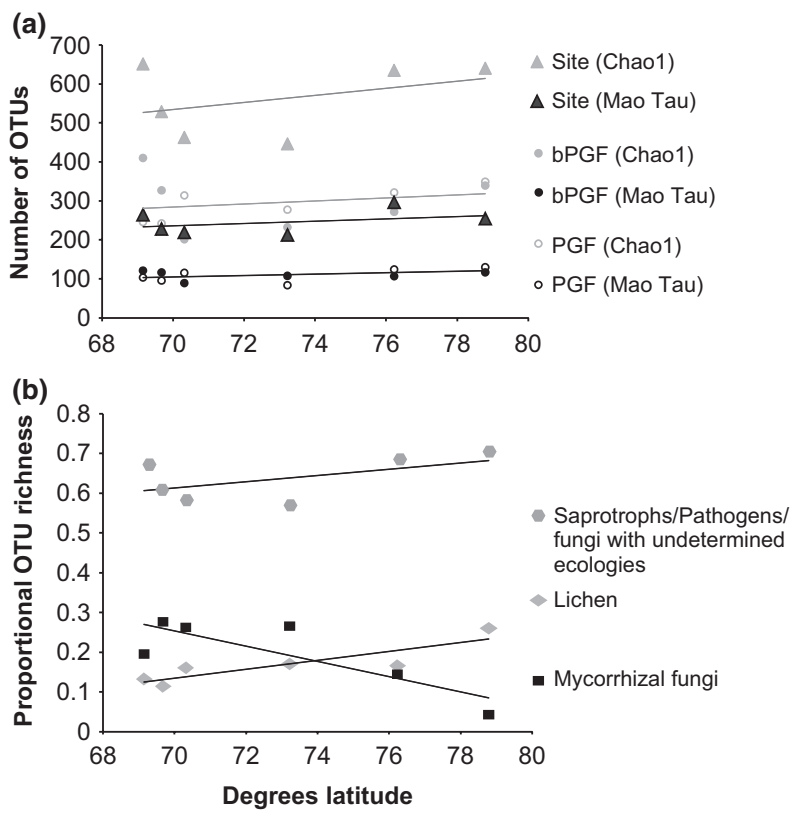

Fig. 3 Linear regression of (a) observed (Mao Tau) and estimated (Chao1) fungal species (OTU) richness of zonal mesic sites and patterned-ground features (PGF, bPGF) along the NAAT. Species richness was based on the pooled soil clones from five PGF and bPGF, which were then rarified to 258 clones to account for technical variation effecting numbers of sequences obtained from each sample. Observed and estimated fungal species richness of PGF and bPGF, and pooled at the site level, show no significant decline with latitude $(P>0.12$, $r^{2}>0.16$ (Mao Tau), $r^{2}>0.06$ (Chao1). (b) Proportional (OTU) richness at sites along the NAAT increased significantly for lichens $\left(P=0.02, r^{2}=0.75\right)$ and decreased significantly for mycorrhizal fungi with latitude $\left(P=0.04, r^{2}=0.68\right)$, while there was no relationship between the group of fungi containing saprotrophs, pathogens and fungi with undetermined ecologies $\left(P=0.27, r^{2}=0.28\right)$ and latitude.

considering functional groups of fungi, we found that the proportion (relative number of species) of lichens to OTU richness at a site increased significantly with latitude. The opposite was found for mycorrhizal fungi (Fig. 3b). This pattern was even stronger for lichens in PGFs $\left(P=0.0417, r^{2}=0.6860\right)$ and for mycorrhizal fungi in bPGFs $\left(P=0.0212, r^{2}=0.7719\right)$. The group of fungi containing saprotrophs, pathogens and fungi with undetermined ecologies showed no changes in their proportion to OTU richness across sites with latitude (Fig. 3b). Relative abundance (proportion) of clones attributable to yeasts in bPGFs increased significantly $\left(P=0.0318, r^{2}=0.7232\right)$ with latitude and relative species richness increased marginally $(P=0.0598$, $\left.r^{2}=0.6287\right)$. There was no relationship between the proportion of yeast clones and species in PGFs with latitude. Dark pigmented fungi showed a unimodal distribution of clone relative abundance and species richness with latitude, with the highest numbers in subzone C (data not shown). There were no significant differences in proportion of clone or species numbers of yeasts and dark pigmented fungi between PGFs and bPGFs (data not shown).

\section{Community structure across the bioclimatic subzones}

MRPP showed that fungal community structure varied across the bioclimatic subzones $(A=0.0711, P<0.001)$. The effect of subzone was stronger when we separated PGF communities $(A=0.075, P<0.001)$ from bPGF communities $(A=0.102, \quad P<0.001)$. The gradual changes in community structure are also apparent in the NMDS ordination biplot (Fig. 4). Along the bioclimatic gradient, the relative abundance of Ascomycota clones and OTUs in PGF and bPGF communities decrease sharply from subzones $\mathrm{E}$ to $\mathrm{D}$ and then increased again towards subzone A (Fig. 5). The opposite pattern occurred for the Basidiomycota, which increased from subzones $\mathrm{E}$ to $\mathrm{D}$ and then decreased towards subzone A (Fig. 5).

Indicator species analysis showed that subzone A was best characterized by particular lichen species (e.g. Verrucariaceae spp.), as well as several pathogenic and saprotrophic taxa (e.g. Phaeosphaeria sp., Leptosphaeria sp.) belonging to the Ascomycota and only a few ectomycorrhizal fungi (e.g. Sistotrema biggsiae, S. sp.) belonging to the Basidiomycota. From subzones D to B, we

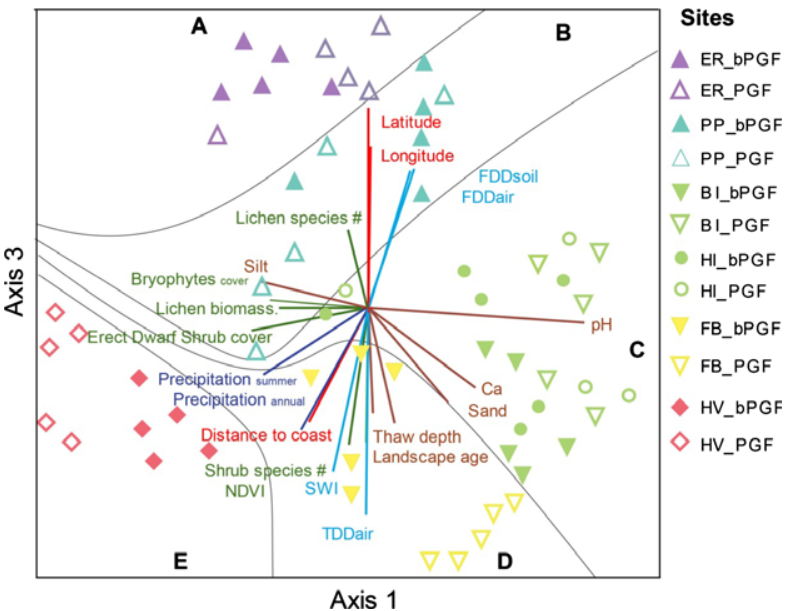

Fig. 4 NMDS ordination of all zonal mesic sites across the NAAT. A through E and colours of points correspond to bioclimate subzones (Fig. 1a). The biplot diagram with the vectors shows the direction and strength of environmental variables with $r^{2}>0.350$. Samples were coded according to location of the study sites: $\mathrm{ER}=$ Ellef Ringnes Island, $\mathrm{PP}=$ Prince Patrick Island, $\mathrm{BI}=$ Banks Island, $\mathrm{HI}=$ Howe Island, $\mathrm{FB}=$ Franklin Bluffs, HV = Happy Valley. Open symbols represent patterned-ground features (PGF), and solid symbols are between patterned-ground features (bPGF). 


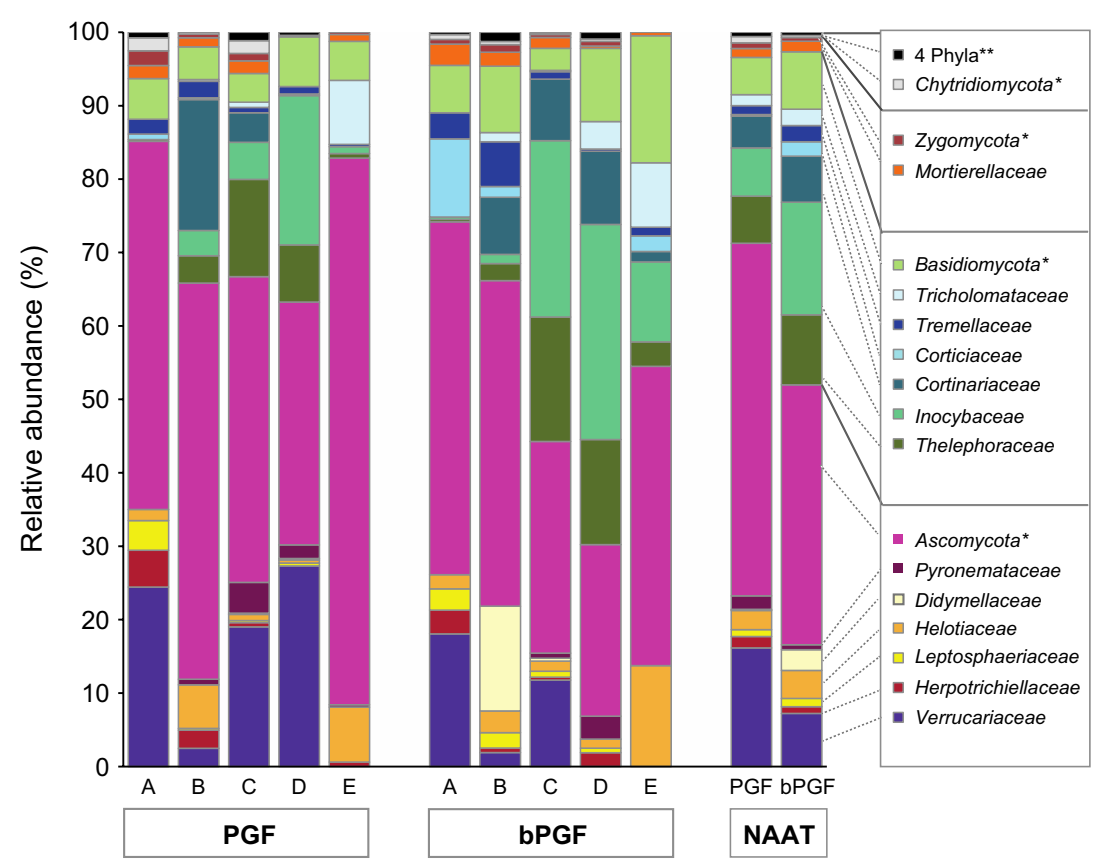

Fig. 5 Relative abundance of fungal families (based on number of clones) in zonal mesic PGF and bPGF across the five bioclimatic subzones (A-E) of the NAAT. Only families that represented more than $1 \%$ of the clones are displayed. *Fungal families representing $<1 \%$ of the total clones and clones that were identified at the order or class and phylum level were grouped at the phylum level. **Glomeromycota, Blastocladiomycota, Neocallimastigomycota and Cryptomycota. observed a decreasing abundance of ectomycorrhizal fungi, including families such as Inocybaceae, Thelephoraceae, Cortinariaceae and Sebacinaceae (Fig. 5). Several Tomentella and Inocybe spp. were indicators for subzone D or C, while Cortinarius minutulus and Cortinarius rubricosus were indicator species for subzone B (Table S6, Supporting Information).

Unlike subzones A-D, in subzone E, $84 \%$ of the sequences found were unique to this subzone. Several Ascomycota families were much more abundant than in other subzones, including the Helotiaceae, Davidiellaceae, Thelebolaceae and Hyaloscyphaceae. Of the Basidiomycota, Tricholomataceae was most abundant in subzone E, while other common families such as Thelephoraceae, Inocybaceae and Cortinariaceae were less abundant (Fig. 5). To investigate the distribution of the unique sequences, we BLAST searched them against a data set from our boreal and arctic studies and found that $73 \%$ of the sequences had top matches in the boreal forests and $27 \%$ across other arctic study sites. Finally, indicator species for subzone E were dominated by endophytes/DSE, for example Rhizoscyphus sp., Phialophora sp., Humicola sp., Thelebolus sp., and by saprotrophs, including Clavaria falcata, Mycena sp. Cryptococcus terricola and Antarctomyces psychrotrophicus. Only a few lichens (Umbilicariaceae sp.) and EMF (Pseudotomentella tristis) appeared to preferentially occur in this subzone.

There was no single OTU that occurred in all five subzones. Instead, five Ascomycota OTUs, namely Tetracladium sp. (OTU3), Cladosporium cladosporioides (OTU41), Gyoerfyella sp. (OTU126), Phialophora sp. (OTU292) and Mortierella sp. (OTU2465), were found across four of the five subzones. BLAST searches in GenBank revealed that these fungi have worldwide geographical distributions.

\section{Fungal community structure within patterned-ground complexes}

Across the bioclimatic gradient, PGFs and bPGFs were dominated by Ascomycota, followed by Basidiomycota. The abundance of Basidiomycota was higher in bPGFs than in PGFs (Fig. 5). Overall, fungal communities differed between PGF and bPGF when combined across all sites, although the effect size was quite small ( $A=0.0077, P<0.001)$. MRPP of PGF and bPGF fungal community structures at each subzone $(5$ subzones $\times 2$ features, PGF/bPGF) showed significant differences in subzones $\mathrm{E}$ to $\mathrm{B}(A=0.033-0.096, P<0.01$; Fig. 4). In contrast, no significant differences occurred between PGF and bPGF fungal communities in subzone $\mathrm{A}$ ( $A=0.013, P>0.20)$.

Indicator species for PGFs across the entire gradient included lichens (Atla sp.) and saprotrophic fungi (Tetracladium sp.) belonging to the Ascomycota. In contrast, indicator species for the bPGFs included ectomycorrhizal (Inocybe exilis, Inocybe fulvipes, Cortinarius helobius) and pathogenic fungi (Phoma sp., Venturia polygoni vivipari) (Table S7, Supporting Information).

\section{Drivers of fungal community structure}

The three axes of the NMDS accounted for $47.6 \%$ of the variation and had a final stress of 18.75. Axis 1 
accounted for $17.1 \%$ of the variation and was mainly correlated with soil-related factors (e.g. $\mathrm{pH}, \mathrm{Ca}^{2+}$, percentage silt), as well as summer precipitation, biomass of lichens and cover of bryophytes and erect dwarf shrubs. Axis 2, which is not shown here, accounted for $11.2 \%$ of the variation and was correlated with a different set of soil factors (sand, clay) and with cover of prostrate dwarf shrubs. Axis 3 accounted for $16.6 \%$ of the variation and represents a biogeographical gradient that was correlated mainly with temperature-related factors such as $\mathrm{TDD}_{\text {air }}, \mathrm{SWI}, \mathrm{FDD}_{\text {soil, }}, \mathrm{FDD}_{\text {air, }}$, thaw depth and location (latitude, longitude). Other factors relating to vegetation included NDVI, number of shrub and lichen species as well as annual precipitation and landscape age corresponded with axis 3 (Fig. 4, Table S2, Supporting Information).

Spearman rank correlations between the strongest environmental factors ( $\mathrm{TDD}_{\text {air }}$ and $\mathrm{pH}$ ) and the most abundant fungal families revealed that $\mathrm{TDD}_{\text {air }}$ was significantly positively correlated $(P \leq 0.05)$ with the abundance of Inocybaceae (0.48), while negative correlations were observed for Mortierellaceae (-0.45), Herpotrichiellaceae $(-0.44)$ and Leptosphaeriaceae $(-0.38)$. Increasing $\mathrm{pH}$ was significantly positively correlated with Thelephoraceae (0.52), Inocybaceae (0.44) and Verrucariaceae (0.45), while it was negatively correlated with Helotiaceae $(-0.58)$ (Table S8, Supporting Information). A partial Mantel test showed that fungal communities were significantly correlated with plant communities when we factored out abiotic environment $(r=0.468, P=0.001)$ and, vice versa, fungal communities were significantly correlated with abiotic environment when we factored out plant communities $(r=0.3769, P=0.007)$.

\section{Discussion}

\section{Fungal diversity in arctic soils}

To date, 4350 fungal species have been described from the entire Arctic (Dahlberg et al. 2013). Through the use of molecular methods, from only six sites we found 1834 OTUs, which encompass eight of the ten known fungal phyla. Considering that more than half of our OTUs (1003) were singletons and that the rarefaction curves did not reach an asymptote, we can expect a much higher fungal richness along the NAAT than has been recorded to date. The dominance of Ascomycota (66\% of the OTUs) and Basidiomycota (26.5\% of OTUs) reflects currently known fungal patterns from the Arctic (Dahlberg et al. 2013) and palaeoecological observations from 16000 - to 32 000-year-old Siberian Permafrost, where Ascomycota comprised $74.2 \%$ and Basidiomycota $10.3 \%$ of the OTUs (Bellemain et al. 2013). This dominance changes in the boreal forest where Ascomycota comprise $55 \%$ of the OTUs and Basidiomycota $39.6 \%$ (Taylor et al. 2014) and becomes the opposite in temperate forests, where Basidiomycota dominate $(54 \%$ of OTUs), followed by Ascomycota (36.1\% of OTUs) (Wubet et al. 2012). Nevertheless, similar to the Arctic, Ascomycota dominate soils of semi-arid grasslands (Porras-Alfaro et al. 2011) and the Alpine tundra (Schadt et al. 2003; Lentendu et al. 2011), suggesting that these fungi are well adapted to dry environments with fluctuating temperatures. The dominance of Ascomycota in the Arctic can be attributed to the high diversity of lichen and saprotrophic as well as parasitic microfungi (Dahlberg et al. 2013). Basidiomycetes are often associated with the presence of EMF and their host plants (Orgiazzi et al. 2013), or large woody debris (Norden et al. 2004). Along the NAAT, many melanized fungi occurred across the Arctic, such as Tomentella, Cenococcum, black yeasts (Mrakia, Exophiala) and DSE (Phialophora, Phialocephala). These fungi are often associated with extreme environments in regard to temperature, UV radiation and drought (Porras-Alfaro et al. 2011). The increased relative abundance and species richness of yeasts in bPGFs with latitude in our study supports the idea that yeasts are abundant in polar regions (Ludley \& Robinson 2008). While the observed fungi along the NAAT represent all major fungal guilds, as in other biomes, there is a preponderance of certain fungal families and genera in the Arctic. The most abundant and diverse families and genera in our study are commonly reported from other regions of the Arctic (Deslippe et al. 2011; Geml et al. 2012b; Singh et al. 2012), the Alpine (Mühlmann et al. 2008) and, to some extent, from Antarctica (Bridge \& Spooner 2012; Goncalves et al. 2012). Overall, our results support the idea that fungi are one of the most diverse known groups of organisms in terrestrial ecosystems of the Arctic (Dahlberg et al. 2013). While comprehensive data for microbial biodiversity (bacteria, archaea and single celled protists) are lacking (Lovejoy 2013), fungi exceed the described species richness of terrestrial mammals $(67$ species) and plants (vascular and bryophytes) (c. 3118 species) as well as terrestrial and freshwater birds that breed in the Arctic (154) and algae (>1700 species) (Payer et al. 2013).

\section{Wide distribution of arctic fungi}

The majority of the 50 most abundant fungal taxa were not limited to the Arctic and other cold habitats. Instead, these OTUs had matches outside the Arctic, with matches to particular OTUs found on every continent. This wide distribution suggests that fungi in the Arctic are not continental-scale endemics, which stands in contrast to fungi from lower latitudes, which often 
do show continental and finer-scale geographical patterns (Taylor et al. 2006; Geml et al. 2008). Nevertheless, OTU16 (Inocybe sp.) appears to be restricted to the Arctic. This parallels observations from Antarctica, where most known fungi are considered to be members of cosmopolitan groups, while only a few taxa appear to be endemic (Bridge \& Spooner 2012). Several studies on smaller spatial or phylogenetic scales have also reported wide distributions of Arctic fungi (Printzen 2008; Jurgens et al. 2009; Geml et al. 2012b; Timling et al. 2012; Tojo \& Newsham 2012). Nevertheless, there are also fungi in the Arctic that are thought to have cospeciated with their high-latitude hosts, such as the rust fungus Melampsora epitea (Smith et al. 2004). These emerging patterns suggest that there might be only a few fungal species that are endemic to the Arctic (Dahlberg et al. 2013).

Despite the emerging evidence that fungi in the Arctic have wide geographical distribution patterns, these observations must be interpreted with caution because we applied only one cut-off for fungal species $(97 \%$ across the ITS region), which may fail to differentiate certain fungal taxa. We expect that a narrower cut-off and/or use of more sensitive markers would detect further species groups in some taxa and might thereby reveal more restricted distributions. To the degree that our ITS types correspond to species, the wide distribution patterns of the dominant fungi from the Arctic suggest that these fungal taxa must be able to disperse across wide terrestrial and transoceanic distances and that they are mainly generalists with wide ecological amplitudes.

\section{Fungal species richness along the latitudinal gradient}

Fungal species richness did not decline with latitude. This parallels observations from maritime Antarctica, where eukaryotes in PGFs, including fungi, did not decline with latitude (Lawley et al. 2004). Our data suggest that the absence of a decline along the bioclimatic gradient is driven mainly by the opposing distribution patterns of two dominant functional groups: lichens and mycorrhizal fungi. The increasing species richness of lichens with latitude coincides with aboveground observations along the NAAT (Kade et al. 2005; Vonlanthen et al. 2008). Nevertheless, this pattern is not identical to findings from other regions of the Arctic and the Antarctic, where species richness of lichens usually declines with latitude (Chernov \& Matveyeva 1997; Peat et al. 2007; Dahlberg et al. 2013). One possible explanation may be related to the decreasing area covered by larger plants (bPGFs) that cause shading and vice versa the increasing area with bare ground (PGFs), which is especially high in subzones A-C (Kade et al. 2005;
Vonlanthen et al. 2008). Lichens would likely face less competition and therefore have a greater chance to establish in open areas (Dahlberg et al. 2013), which might lead to higher species richness. The species richness decline of mycorrhizal fungi could be due to a declining number of potential host species, as suggested by Newsham et al. (2009). Indeed, the number of potential host species for ectomycorrhizal and ericoid fungi in the investigated plant communities declined with increasing latitude along the NAAT. On the other hand, richness of vascular plants did not decline at the plot scale along the NAAT (Kade et al. 2005; Vonlanthen et al. 2008). The decline of mycorrhizal fungi warrants further investigation, using next-generation sequencing technologies in order to overcome undersampling of these diverse communities, along with comparisons of plants and fungi at multiple spatial scales.

\section{Community structures and environmental drivers}

Bioclimatic subzones. Fungal communities of neighbouring subzones along the bioclimatic gradient of the NAAT were most similar. This corroborates not only our previous findings for root-tip EMF associated with Dryas integrifolia and Salix arctica (Timling et al. 2012), but coincides with changes in zonal plant communities and abiotic environments along the same gradient (Walker et al. 2011). Climate, including temperaturerelated factors and annual precipitation, exerts the strongest effect at the regional scale across subzones. Climate was correlated with changes in plant productivity (NDVI) and variation in plant communities; especially in warmer subzones, the number of shrub species increases, while the number of lichen species decreases, which consequently drives the abundance and diversity of some ectomycorrhizal families (e.g. Inocybaceae) and lichen-associated fungi. Partial Mantel tests showed that fungal community structures in our study were correlated with both plant communities and abiotic environmental variables. Such interactions were also observed along a maritime Antarctic latitudinal gradient, where fungal communities were correlated with the interaction between latitude-dependent environments and vegetation type (Yergeau et al. 2007).

While climate and the resulting plant communities seem to be the major drivers in subzones $A$ to $D, p H$ and the resulting plant communities appear to be the key drivers at the junction between subzones D and E, where we observed a major transition in fungal communities. A strong effect of $\mathrm{pH}$ on community structures has been observed or bacteria and fungi across different biomes (e.g. Toljander et al. 2006; Chu et al. 2010) and for plants along the NAAT (Walker et al. 2011). The majority of fungal OTUs $(84 \%)$ in subzone $\mathrm{E}$ were 
unique to this site/subzone. This transition coincides with the change from nonacidic (subzones A to D) to acidic (subzone E) tundra and a change from a sedge/ prostrate dwarf shrub/moss tundra to a tussock sedge/ erect dwarf shrub/moss tundra; the latter includes an abundance of boreal plant species that are not common in nonacidic zonal plant communities further north, such as Betula nana, Rhododendron tomentosum subsp. decumbens (Ledum palustre subsp. decumbens), Vaccinium vitis-idea, Polygonum bistorta and Sphagnum spp. as well as an increased cover of Eriophorum vaginatum (Walker et al. 1994). Yurtsev (1994) considers subzone E to be an extension of the boreal region but without trees. It is interesting to speculate that the high proportion of fungal OTUs that are shared with boreal regions might facilitate future expansion of treeline into the Arctic. Reithmeier (2011) observed that conifers grew best in soils of Salix spp. from above treeline and concluded that the EMF of Salix spp. could potentially facilitate the establishment of conifers at higher latitudes by acting as ectomycorrhizal nurse plants. Additionally, B. nana maintained EMF through tundra fire, potentially facilitating the revegetation by shrubs and possibly the expansion of trees into the Arctic (Hewitt et al. 2013).

Although subzone A lacks woody species, we found EMF in these soils. These EMF sequences most likely arose from spores because EMF are obligate mutualists that require hosts for germination and survival (Ishida et al. 2008). This suggests that DNA-based soil analysis may include fungi that are not actively growing at the time of sampling. Longevity of fungal spores is estimated to vary from 1 year to many decades (Ishida et al. 2008; Bruns et al. 2009). One could hypothesize that these spores might provide inoculum to facilitate shrub establishment in this subzone, if climate permits.

PGFs and bPGFs. The distinct fungal communities of PGFs vs. bPGFs along the bioclimatic gradient parallel structure of plant communities at the same sites (Walker et al. 2011). The only exception occurred in subzone A, where fungal community structures did not differ significantly between PGFs and bPGFs, despite hosting different plant communities (Vonlanthen et al. 2008). This is not surprising because, in comparison with the other subzones, PGFs in subzone A generally experience less frost heave and physical disturbance, and bPGFs develop in soil cracks, which are sparsely vegetated (Raynolds et al. 2008; Romanovsky et al. 2008). Most of the patterned-ground at subzone A is due to thermal and desiccation cracking at a fine scale (20-30 cm) (Walker et al. 2008). The sampling approach we used did not clearly differentiate the soils collected from the fine-scale microhabitats of cracks vs. the noncracked adjacent area towards the centres of the polygons. These bPGFs host many lichens but lack the woody species that are common in all other subzones (Walker et al. 2011). The fundamentally different type of disturbance in subzone A compared to other subzones leads to very similar abiotic environments across these features.

The significant differences between fungal communities of PGF and bPGF in subzones B through E are likely a result of the local microenvironments created by different types of physical disturbances such as frost heave in subzones $\mathrm{C}$ to $\mathrm{E}$ and cracking in subzones $\mathrm{B}$ to $\mathrm{A}$, and the resulting differences in plant communities (Raynolds et al. 2008). Temperature-related factors $\left(\mathrm{TDD}_{\text {Soil }}, \mathrm{FDD}_{\text {Soil, }} \mathrm{TDD}_{\text {air }}\right)$ and cover and species richness of plant functional types were related to fungal communities at the regional scale (subzones). At the local scale, differences in soil temperature $\left(\mathrm{TDD}_{\mathrm{Soil}}\right)$ were pronounced and showed the strongest differences in subzones C and D, with PGFs being up to 200-500 thawing degrees warmer than the adjacent bPGFs. Additionally, PGFs in subzone D experienced annual frost heave of up to $20 \mathrm{~cm}$, causing distinct disturbances of the soil (Walker et al. 2011).

Ascomycota dominate PGFs, where various lichens are significant indicator species. However, Ascomycota include other functional groups, such as mycorrhizal taxa, saprotrophs and pathogens, underlining the functional diversity within these seemingly 'barren' features. In contrast, EMF and saprotrophs are the major components of the basidiomycetes and are also indicator species for bPGFs. The dominance of basidiomycetes in bPGFs at subzones $\mathrm{C}$ and $\mathrm{D}$, coincides with the highest cover and biomass of deciduous (e.g. Salix spp.) and evergreen ectomycorrhizal shrubs (e.g. D. integrifolia) (Walker et al. 2011). Generally, saprotrophic fungi of both phyla were abundant throughout PGFs and bPGFs. Although percentage organic carbon and $\mathrm{C}: \mathrm{N}$ ratio and soil moisture were generally higher in bPGFs, PGFs were generally warmer and drier, which could favour decomposition (Michaelson et al. 2008). Not surprisingly, pathogenic fungi occurred more often in bPGFs, where plants act as hosts. The high spatial heterogeneity of fungal communities of PGFs and bPGFs contributes to a high local alpha diversity of these sites along the NAAT.

Overall fungal communities in patterned-ground ecosystems are not only shaped by climate, physical and biological interactions, but also represent an integral part of the interactions that drive patterned-ground ecosystems directly by facilitating plant nutrition and establishment as plant symbionts and decomposers and indirectly by stabilizing the ground in the form of lichens in soil crusts and hyphae binding soil aggregates. Soil crusts facilitate the establishment of plants in these disturbed microhabitats (Gold 1998; Walker et al. 
2012). Over time, plants mask the PGFs and change their biophysical properties (Walker et al. 2011). These roles are especially apparent in the southern part of the Arctic tundra biome, and future studies should address the functional role of fungi in the evolution of patterned-ground ecosystems.

\section{Conclusions}

This is the first report of soil fungal communities in patterned-ground ecosystems and the first to describe communities across the entire bioclimatic gradient of the North American Arctic. With the inclusion of all fungal groups found in soil in our study, we extend and substantiate previous findings from studies of EMF root-tip communities in the Arctic. Namely, fungal communities in the North American Arctic are diverse, supporting the notion that fungi are the most species-rich eukaryotes in the Arctic. While fungal communities show no species richness decline with latitude, the species richness is maintained by the opposing patterns in the relative species richness of two functional groups, with lichens increasing and mycorrhizal fungi decreasing with latitude. The wide distribution of the most abundant OTUs supports increasing evidence that many fungi in the Arctic must be excellent dispersers with wide ecological amplitudes. Nevertheless, despite their wide geographical distributions, arctic fungi show niche preferences with regard to climate and vegetation at the regional scale across bioclimatic subzones and at a local scale across patterned-ground features and their associated abiotic environments and plant communities. Fungal community structures are driven by the same primary abiotic environmental factors as plant communities, which are temperature, disturbance and $\mathrm{pH}$. However, they are also highly correlated with the composition of plant communities with which they interact as mutualists, pathogens and decomposers. If we consider our studies along the NAAT as an analog to climate warming, we expect that a warming climate associated with enhanced colonization of patternedground features by vascular plants will initiate a suite of biophysical changes that will affect fungal community composition and structure not only at the species level, but also at the level of functional groups. In particular, we would expect an increase in fungi that are symbiotic with plants. These changes, in turn, may alter ecosystem functioning of patterned-ground features in the Arctic.

\section{Acknowledgements}

The authors would like to thank Hilmar Maier and Edie Barbour for helping with graphical designs, Martha Raynolds and
Ronald Daanen for conceptual discussions, VECO Polar Resources and Aklak Air for logistical support, Parks Canada and the Inuvialuit community for supporting our research on their lands as well as three anonymous reviewers for their helpful comments. The authors acknowledge the generous support of US National Science Foundation Grants ARC0425517 to DAW, ARC-0632332 to DLT, and fellowships by EPSCoR, the UAF-Graduate School and the Institute of Arctic Biology to IT and a Global Change Student Research Grant to IT.

\section{References}

Altschul SF, Madden TL, Schaeffer AA et al. (1997) Gapped BLAST and PSI-BLAST: a new generation of protein database search programs. Nucleic Acids Research, 25, 3389-3402.

Bellemain E, Davey ML, Kauserud H et al. (2013) Fungal paleodiversity revealed using high-throughput metabarcoding of ancient DNA from arctic permafrost. Environmental Microbiology, 15, 1176-1189.

Bjorbaekmo MFM, Carlsen T, Brysting A et al. (2010) High diversity of root associated fungi in both alpine and arctic Dryas octopetala. BMC Plant Biology, 10, 244.

Blaalid R, Carlsen T, Kumar S et al. (2012) Changes in the rootassociated fungal communities along a primary succession gradient analysed by 454 pyrosequencing. Molecular Ecology, 21, 1897-1908.

Bridge PD, Spooner BM (2012) Non-lichenized Antarctic fungi: transient visitors or members of a cryptic ecosystem? Fungal Ecology, 5, 381-394.

Bruns TD, Peay KG, Boynton PJ et al. (2009) Inoculum potential of Rhizopogon spores increases with time over the first $4 \mathrm{yr}$ of a 99-yr spore burial experiment. New Phytologist, 181, 463470.

CAVM-Team (2003) Circumpolar Arctic vegetation Map. Scale 1:7,500,000. Conservation of Arctic Flora and Fauna (CAFF) Map No.1. U.S. Fish and Wildlife Service, Anchorage, Alaska.

Chernov YI, Matveyeva NV (1997) Arctic ecosystems in Russia. In: Ecosystems of the World: Polar and Alpine Tundra(ed Wielgolaski FE), pp. 361-507. Elsevier, Amsterdam.

Chu HY, Fierer N, Lauber CL, Caporaso JG, Knight R, Grogan $P$ (2010) Soil bacterial diversity in the Arctic is not fundamentally different from that found in other biomes. Environmental Microbiology, 12, 2998-3006.

Clemmensen KE, Michelsen A (2006) Integrated long-term responses of an arctic-alpine willow and associated ectomycorrhizal fungi to an altered environment. Canadian Journal Of Botany, 84, 831-843.

Colwell RK (2006) EstimateS. Statistical Estimation of Species Richness and Shared Species from Samples. Department of Ecology and Evolutionary Biology, University of Connecticut, Storrs, Connecticut. Available from: http://viceroy.eeb. uconn.edu/estimates

Dahlberg A, Bültmann H, Cripps CL et al. (2013) Fungi. In: Arctic Biodiversity Assessment. Status and Trends in Arctic Biodiversity. (ed. Meltofte H), pp. 354-371. Conservation of Arctic Flora and Fauna (CAFF), Akureyri.

Deslippe JR, Hartmann M, Mohn WW, Simard SW (2011) Long-term experimental manipulation of climate alters the ectomycorrhizal community of Betula nana in Arctic tundra. Global Change Biology, 17, 1625-1636. 
Edgar RC, Haas BJ, Clemente JC, Quince C, Knight R (2011) UCHIME improves sensitivity and speed of chimera detection. Bioinformatics, 27, 2194-2200.

Fujimura KE, Egger KN (2012) Host plant and environment influence community assembly of High Arctic root-associated fungal communities. Fungal Ecology, 5, 408-418.

Fujiyoshi M, Yoshitake S, Watanabe K et al. (2011) Successional changes in ectomycorrhizal fungi associated with the polar willow Salix polaris in a deglaciated area in the High Arctic, Svalbard. Polar Biology, 34, 667-673.

Gardes M, Bruns TD (1993) ITS Primers with enhanced specificity for Basidiomycetes: application to the identification of mycorrhizae and rusts. Molecular Ecology, 2, 113-118.

Geml J, Tulloss RE, Laursen GA, Sazanova NA, Taylor DL (2008) Evidence for strong inter- and intracontinental phylogeographic structure in Amanita muscaria, a wind-dispersed ectomycorrhizal basidiomycete. Molecular Phylogenetics and Evolution, 48, 694-701.

Geml J, Kauff F, Brochmann C et al. (2012a) Frequent circumarctic and rare transequatorial dispersals in the lichenised agaric genus Lichenomphalia (Hygrophoraceae, Basidiomycota). Fungal Biology, 116, 388-400.

Geml J, Timling I, Robinson $\mathrm{CH}$ et al. (2012b) An arctic community of symbiotic fungi assembled by long-distance dispersers: phylogenetic diversity of ectomycorrhizal basidiomycetes in Svalbard based on soil and sporocarp DNA. Journal of Biogeography, 39, 74-88.

Gold WG (1998) The influence of cryptogamic crusts on the thermal environment and temperature relations of plants in a high arctic polar desert, Devon Island, N.W.T., Canada. Arctic and Alpine Research, 30, 108-120.

Goncalves VN, Vaz ABM, Rosa CA, Rosa LH (2012) Diversity and distribution of fungal communities in lakes of Antarctica. FEMS Microbiology Ecology, 82, 459-471.

Hewitt RE, Bent E, Hollingsworth TN, Chapin FS III, Taylor DL (2013) Resilience of Arctic mycorrhizal fungal communities after wildfire facilitated by resprouting shrubs. Ecoscience, 20, 296-310.

http://permafrost.gi.alaska.edu (2013) Geophysical Institute Permafrost Laboratory. Site Information and Historical Data Access.

Huson DH, Auch AF, Qi J, Schuster SC (2007) MEGAN analysis of metagenomic data. Genome Research, 17, 377-386.

Ishida TA, Nara K, Tanaka M, Kinoshita A, Hogetsu T (2008) Germination and infectivity of ectomycorrhizal fungal spores in relation to their ecological traits during primary succession. New Phytologist, 180, 491-500.

Jurgens JA, Blanchette RA, Filley TR (2009) Fungal diversity and deterioration in mummified woods from the ad Astra Ice Cap region in the Canadian High Arctic. Polar Biology, 32, 751-758.

Kade A, Walker DA, Raynolds MK (2005) Plant communities and soils in cryoturbated tundra along a bioclimate gradient in the Low Arctic, Alaska. Phytocoenologia, 35, 761-820.

Laursen GA (1975) Higher fungi in soils of coastal Arctic tundra plant communities. Ph.D. Dissertation. Virginia Polytechnic Institute and State University, Department of Biology. 396pp. Copyrighted 1976. University Microfilms, Ann Arbor, Michigan.
Lawley B, Ripley S, Bridge P, Convey P (2004) Molecular analysis of geographic patterns of eukaryotic diversity in Antarctic soils. Applied \& Environmental Microbiology, 70, 5963-5972.

Lentendu G, Zinger L, Manel S et al. (2011) Assessment of soil fungal diversity in different alpine tundra habitats by means of pyrosequencing. Fungal Diversity, 49, 113-123.

Lovejoy C (2013) Microorganisms. In: Biodiversity Assessment. Status and Trends in Arctic Biodiversity(ed Metlofte H), pp. 372-383. Arctic Conservation of Arctic Flora and Fauna, Akureyri.

Ludley KE, Robinson CH (2008) Decomposer Basidiomycota in Arctic and Antarctic ecosystems. Soil Biology and Biochemistry, 40, 11-29.

McCune B, Mefford MJ (2006) PC-ORD. Multivariate Analysis of Ecological Data. Version 5. MjM Software Design, Gleneden Beach, Oregon.

Michaelson GJ, Ping CL, Epstein H, Kimble JM, Walker DA (2008) Soils and frost boil ecosystems across the North American Arctic Transect. Journal of Geophysical Research-Biogeosciences, 113, G03S11.

Mühlmann O, Bacher M, Peintner U (2008) Polygonum viviparum mycobionts on an alpine primary successional glacier forefront. Mycorrhiza, 18, 87-95.

Newsham KK, Upson R, Read DJ (2009) Mycorrhizas and dark septate root endophytes in polar regions. Fungal Ecology, 2, $10-20$.

Norden B, Ryberg M, Gotmark F, Olausson B (2004) Relative importance of coarse and fine woody debris for the diversity of wood-inhabiting fungi in temperate broadleaf forests. Biological Conservation, 117, 1-10.

Orgiazzi A, Bianciotto V, Bonfante P et al. (2013) 454 Pyrosequencing analysis of fungal assemblages from geographically distant, disparate soils reveal spatial patterning and a core mycobiome. Diversity, 5, 73-98.

Payer DC, Josefson AB, Fjeldså J (2013) Species diversity in the Arctic. In: Biodiversity Assessment. Status and Trends in Arctic Biodiversity(ed Metlofte H), pp. 66-77. Arctic Conservation of Arctic Flora and Fauna, Akureyri.

Peat HJ, Clarke A, Convey P (2007) Diversity and biogeography of the Antarctic flora. Journal of Biogeography, 34, 132146.

Peterson RA, Krantz WB (2008) Differential frost heave model for patterned-ground formation: corroboration with observations along the North American Arctic Transect. Journal of Geophysical Research-Biogeosciences, 113, G03S04.

Ping CL, Michaelson GJ, Jorgenson MT et al. (2008) High stocks of soil organic carbon in the North American Arctic region. Nature Geoscience, 1, 615-619.

Porras-Alfaro A, Herrera J, Natvig DO, Lipinski K, Sinsabaugh RL (2011) Diversity and distribution of soil fungal communities in a semiarid grassland. Mycologia, 103, 1021.

Printzen C (2008) Uncharted terrain: the phylogeography of arctic and boreal lichens. Plant Ecology \& Diversity, 1, 265271.

Raynolds MK, Walker DA, Munger CA, Vonlanthen CM, Kade AN (2008) A map analysis of patterned-ground along a north American Arctic Transect. Journal of Geophysical Research-Biogeosciences, 113, G03S03. 
Razzhivin VY (1999) Zonation of vegetation in the Russian Arctic. In: The Species Concept in the High North- A Panarctic Flora Initiative(eds Nordal IR \& Razzhivin VY), pp. 113-130. The Norwegian Academy of Science and Letters 38, Det Norske Videnskaps-Akademi, Oslo.

R-Development-Team (2008) R: A Language and Environment for Statistical Computing. R Foundation for Statistical Computing, Vienna, Austria.

Reithmeier L (2011) Facilitation of ectomycorrhizal colonization of Picea mariana by alternate host plants above treeline. MSc-thesis, Dalhousie University, Halifax, Nova Scotia.

Rinnan R, Michelsen A, Baath E, Jonasson S (2007) Fifteen years of climate change manipulations alter soil microbial communities in a subarctic heath ecosystem. Global Change Biology, 13, 28-39.

Romanovsky VE, Marchenko SS, Daanen R, Sergeev DO, Walker DA (2008) Soil climate and frost heave along the permafrost/ecological North American Arctic transect. Ninth International Conference on Permafrost. Fairbanks, AK, June 28July 3. Vol. 2, Part VI, 1519-1524.

Schadt CW, Martin AP, Lipson DA, Schmidt SK (2003) Seasonal dynamics of previously unknown fungal lineages in tundra soils. Science, 301, 1359-1361.

Singh SM, Singh SK, Yadav LS, Singh PN, Ravindra R (2012) Filamentous soil fungi from Ny-Alesund, Spitsbergen, and screening for extracellular enzymes. Arctic, 65, 45-55.

Smith JA, Blanchette RA, Newcombe G (2004) Molecular and morphological characterization of the willow rust fungus, Melampsora epitea, from arctic and temperate hosts in North America. Mycologia, 96, 1330-1338.

Taylor DL, Houston S (2011) A bioinformatics pipeline for sequence-based analyses of fungal biodiversity. Methods in Molecular Biology, 722, 141-155.

Taylor JW, Turner E, Townsend JP, Dettman JR, Jacobson D (2006) Eukaryotic microbes, species recognition and the geographic limits of species: examples from the kingdom Fungi. Philosophical Transactions of the Royal Society B-Biological Sciences, 361, 1947-1963.

Taylor DL, Booth MG, Mcfarland JW et al. (2008) Increasing ecological inference from high throughput sequencing of fungi in the environment through a tagging approach. Molecular Ecology Resources, 8, 742-752.

Taylor DL, Hollingsworth TN, McFarland JW et al. (2014) A first comprehensive census of fungi in soil reveals both hyperdiversity and fine scale niche partitioning. Ecological Monographs, 84, 3-20.

Timling I, Taylor DL (2012) Peeking through a frosty window: molecular insights into the ecology of Arctic soil fungi. Fungal Ecology, 5, 419-429.

Timling I, Dahlberg A, Walker DA et al. (2012) Distribution and drivers of ectomycorrhizal fungal communities across the North American Arctic. Ecosphere, 3, 111.

Tojo M, Newsham KK (2012) Snow moulds in polar environments. Fungal Ecology, 5, 395-402.

Toljander JF, Eberhardt U, Toljander YK, Paul LR, Taylor AFS (2006) Species composition of an ectomycorrhizal fungal community along a local nutrient gradient in a boreal forest. New Phytologist, 170, 873-883.

Vonlanthen CM, Walker DA, Raynolds MK et al. (2008) Patterned-ground plant communities along a bioclimate gra- dient in the High Arctic, Canada. Phytocoenologia, 38, 2363.

Vysotsky GN (1909) On phyto-topological maps, approaches to their compilation and their practical significance. Pochvovedenie, 2, 97-124 (in Russian).

Walker MD, Walker DA, Auerbach NA (1994) Plantcommunities of a tussock tundra landscape in the Brooks Range Foothills, Alaska. Journal of Vegetation Science, 5, 843-866.

Walker DA, Raynolds MK, Daniels FJA et al. (2005) The Circumpolar Arctic vegetation map. Journal of Vegetation Science, 16, 267-282.

Walker MD, Wahren CH, Hollister RD et al. (2006) Plant community responses to experimental warming across the tundra biome. Proceedings of the National Academy of Sciences of the United States of America, 103, 1342-1346.

Walker DA, Epstein HE, Romanovsky VE et al. (2008) Arctic patterned-ground ecosystems: a synthesis of field studies and models along a North American Arctic Transect. Journal of Geophysical Research-Biogeosciences, 113, G03S01.

Walker DA, Kuss P, Epstein HE et al. (2011) Vegetation of zonal patterned-ground ecosystems along the North America Arctic bioclimate gradient. Applied Vegetation Science, 14, 440 463.

Walker DA, Matyshak G, Frost GV, Zhurbenko M, Afonina O (2012) High cover, biomass, and NDVI of biological soil crusts on Hayes Island, Franz Josef Land, Russia. Tenth International Conference on Permafrost, Salekhard, Russia, 634 635.

Wallenstein MD, McMahon S, Schimel J (2007) Bacterial and fungal community structure in Arctic tundra tussock and shrub soils. FEMS Microbiology Ecology, 59, 428-435.

Washburn AL (1980) Geocryology: A Survey of Periglacial Processes and Environments. 406p, John Wiley, New York.

White TJ, Bruns TD, Lee S, Taylor JW (1990) Amplification and direct sequencing of fungal ribosomal RNA genes for phylogenetics. In: PCR protocols: a guide tomethods and applications (eds Innis MA, Gelfand DH, Sninsky JJ \& White TJ), pp. 315-322. Academic Press, New York.

Wubet T, Christ S, Schoning I et al. (2012) Differences in soil fungal communities between European Beech (Fagus sylvatica L.) dominated forests are related to soil and understory Vegetation. PLoS ONE, 7, e47500. doi: 10.1371/journal.pone. 0047500 .

Yergeau E, Bokhorst S, Huiskes AHL et al. (2007) Size and structure of bacterial, fungal and nematode communities along an Antarctic environmental gradient. FEMS Microbiology Ecology, 59, 436-451.

Yurtsev BA (1994) Floristic division of the Arctic. Journal of Vegetation Science, 5, 765-776.

I.T., D.W. and L.T. designed and conducted the research. I.T. collected soils, extracted DNA, analysed the data and wrote the first draft of the manuscript. C.N. and N.L. facilitated the sequencing. All authors edited the manuscript. 


\section{Data accessibility}

DNA sequences: GenBank Accession nos KC965108KC966374, KF296719-KF297285.

Distributions of OTUs in PGF/bPGF across the six sampling locations along the NAAT are provided in Table S3, Supporting Information.

\section{Supporting information}

Additional supporting information may be found in the online version of this article.

Table S1 Locations and characteristics of the dry and wet sampling sites at along the North American Arctic Transect (NAAT).

Table S2 Correlations coefficients $\left(r^{2}\right)$ for variables in the NMDS ordination of zonal mesic sites along the NAAT.
Table S3 NCBI BLAST-matches and distribution of 1834 OTUs (7834 clones) in patterned-ground features (PGFs) and between patterned-ground features (bPGFs) along the NAAT.

Table S4 Distribution of clones/OTUs assigned to various taxonomic levels across patterned-ground features (PGFs) and between patterned-ground features (bPGFs) in five subzones in the North American Arctic

Table S5 Geographical distribution of GenBank matches to the 50 most abundant OTUs observed in patterned-ground ecosystems along the NAAT.

Table S6 Indicator species of zonal mesic patterned-ground ecosystems for the five bioclimatic subzones (A-E) along the NAAT.

Table S7 Indicator species for zonal mesic PGF and bPGF along the NAAT.

Table S8 Spearman rank correlation coefficients of thawing degree days $\left(\mathrm{TDD}_{\text {air }}\right)$ and $\mathrm{pH}$ and most abundant fungal families in zonal mesic sites along the NAAT. 